\title{
Relationship between Religious Orientation, Emotional Maturity and Identity Styles with Marital Infidelity
}

\author{
Samaneh Ebrahimi Khasmakhi \\ Master of Psychology, Psychology Department, Faculty of Humanities, \\ Science and Research Branch, Islamic Azad University, Tehran, Iran \\ Afshin Salahin \\ Assistant Professor, Psychology Department, Iran
}

Doi:10.19044/esj.2018.v14n29p129 URL:http://dx.doi.org/10.19044/esj.2018.v14n29p129

\begin{abstract}
Marital infidelity is a multi-faceted problem that has the tendency of an interpersonal and environmental dimension. This paper focuses on investigating the relationship between religious orientation, emotional maturity, and identity styles with talent of marital infidelity in married women and men in Tehran, Iran. The research method was by correlation and the study sample consists of 121 subjects (62 women and 59 men) who were selected by available sampling method. Marital infidelity, religious orientation, emotional maturity, and identity styles questionnaires were used to collect data. Correlation method and regression analysis was used to determine the predictive factors. The results indicated that there was no significant relationship between religious orientation and marital infidelity. On the other hand, there was a positive and significant relationship between emotional maturity and marital infidelity. The results also showed that from the four identity styles, only confused and committed identity styles are related to marital infidelity. Regression results also showed that commitment and emotional maturity in two steps significantly predicted $22 \%$ variance of marital infidelity.
\end{abstract}

Keywords: Marital infidelity, emotional maturity, identity styles, religious

\section{Introduction}

The family is the oldest social unit and is regarded as the core of social organizations, which has many activists. The family acts as a cellular tissue for social organs. However, it begins when a firm and permanent bond is shaped between a woman and a man, which is defined as marriage. One of the important activities of the family is the establishment of a relationship 
between men and women, and the development of psychological health that would serve as a source of peace for both of them (Teimoori, Qolamali Lawasani \& Bakhshayesh, 2013). Although the accepted principle of sexual behavior in Iranian society is Monogamy, marital betrayal has become an important problem for many couples. Marital infidelity is the breach of the two person's relationship commitment, which leads to the degree of emotional and physical intimacy with an individual outside the couple's relationship (Aviram \& Amichai-Hamburger, 2005). Other researchers considered betrayal to be sexual intercourse beyond marital relationships. Here, a woman or man uses the form of Internet sex, secret relationships, secret use of painting, photographs, and sexual stimulants with another person who is not his/her partner (Whitty, 2002). According to the study of Tsapelas et al. (2010), the occurrence of marital betrayal in American women is $26 \%$ to $70 \%$, and between American men is $33 \%$ to $75 \%$. In Iran, due to the legal and cultural limitations of this phenomenon, there is no precise statistics. According to one of the most documentary studies in this area in the United States, 21 percent of men and 11 percent of women experience extramarital relationship in the course of their lives (Snyder, Baucom, \& Gordon, 2008). A study sample from Tehran showed that 33 percent of marital infidelity has been reported (Teimoori, Qolamali, \& Bakhshayesh, 2013). However, a great deal of research confirms the fact that marital infidelity is the main reason for the disintegration of marital relationships and marital conflicts (Peleg, 2008). Additionally, it is the main reason for divorce (Amato \& Rogers, 1997). Participating in relationships outside the marital domain has a significant prevalence in the clinical and normal environment, causing severe emotional outcomes and disturbances to the perpetrators and their spouses. Probably, a lot of counselor or couples therapists were often confronted with psychological damages of marital relationships after the discovering of an illicit relationship (Rubinstein \& Ivanir, 1999). Psychotherapists reported that the wives they betrayed often experience feelings such as anger, low self-esteem, perpetuation, depression and helplessness, while their husband also experience feelings of shame, guilt, hesitation, anger, and disappointment (Brown, 2001; Glass \& Wright, 2007). Extreme emotional distress is often associated with cognitive disturbances after disclosure of marital betrayal. One of the most important disturbances experienced by a spouse who has been betrayed is intense rumination that can be so severe and uncontrollable, and which can disturb daily function and concentration (Brown, 2001; Glass \& Wright, 2007). Another important cognitive response is a change in the individual's beliefs and feelings of insecurity (Brown, 2001; Glass \& Wright, 2007).

Despite the fact that marital infidelity is a common concept, it is negligible. As a result of this taboo, there are no clear studies on this topic. Therefore, the present study examines this topic by considering three factors, 
religious orientation, emotional maturity and identity styles, which might have contributed to talent of marital infidelity. The reason for choosing a religious variable was the cultural and religion of Islam in Iran, which forbade marital infidelity as major sin. Also, other variables were correlated based on theories. Therefore, this paper focuses on investigating the relationship between religious orientation, emotional maturity, and identity styles with talent of marital infidelity in married people in Tehran.

\section{Method}

The method of this study was correlation and the sample was 321 people (162 women and 159 men) who were selected by available sampling method. The mean of the sample age and the duration of the marriage were $37.2 \pm 1.23$ and 5.21 \pm 3.76 , respectively; and the most frequency of sample had bachelor. The instruments used for collecting data were Marami and Khademi marital betrayal talents (2013), Allport religious orientation questionnaire (1950), Singh and Bhargave emotional maturity questionnaire (1981), and Berzonsky identity styles questionnaire (2002). Thus, the full description of each scale is given below:

1. Marital Betrayal Talents: This questionnaire consists of 52 items used to measure marital infidelity talents. The construction and standardization of marital betrayal talent in Iranian society was carried out by Marami and Khademi in 2012 on 484 couples. This instrument can also be used as a diagnostic tool for couples seeking marriage counseling and counseling before marriage, and those seeking to strengthen their marital relationship. Marami and Khademi (2013) determine the validity of the scale by construct validity (Correlation with Enrich's marital satisfaction test), internal consistency, and factor analysis. To determine the reliability of the scale, Cronbach's alpha coefficient was used. Scoring of this questionnaire was five Likert options (totally disagree '0', to totally agree '4').

2. Religious Orientation Questionnaire: This questionnaire was made by Allport in 1950 and it consists of 20 questions. 11 questions (1-12) measures external religious orientation and 9 questions (13-21) assess the internal religious orientation. Scoring of this questionnaire was five Likert options (totally disagree '1', to totally agree '5'). Allport reported a divergent correlation between the internal and external religious orientation $(r=-0.21)$ (Allport, 1968).

3. Emotional Maturity Questionnaire: This questionnaire, designed by Singh and Bhargave (1981), consists of 48 questions. The purpose of this questionnaire is to examine the different dimensions of emotional maturity (emotional insecurity, emotional return, personality collapse, social incompatibility and lack of independence). The response spectrum is based on 
the Likert scale. Also, the validity and reliability have been confirmed by Singh and Bhargave (1981).

4: Identity Styles Questionnaire: Identity styles questionnaire was originally created by Berzonsky (1989), and was then re-examined twice by him. It was designed to measure the social cognitive processes that teenagers use to deal with identity issues. The questionnaire consists of 40 items with three types of identity styles; informative, normative, and avoiding-confusion styles. The respondents' answers to the questions are in the form of a 5-point Likert scale, which ranges from I totally disagree '1' to totally agree '5' (Berzonsky, 1989). Berzonsky (2002) reported that accepted Cronbach's alpha for informational, normative, and confusing-avoidance styles were $0.62,0.66$ and 0.73 , respectively.

\section{Findings}

According to the results, the most number of samples had a bachelor's degree and the fewer number had elementary education. Also, the most frequency was related to housekeeping and the lowest frequency was related to the occupation of the professor, the driver, and the graphic artist. The most frequency of the sample had an average economic situation. Table 1 shows the mean and standard deviations of the subscale of the variables. According to the results, the highest mean was related to the total emotional maturity, and social incompatibility had a lowest mean.

Table 1. Average and standard deviations of research variables and subscales

\begin{tabular}{cccc}
\hline Variable & Subscale & Mean & Standard Deviation \\
\hline Age & - & $34 / 99$ & $7 / 59$ \\
\hline Marital infidelity & - & $59 / 22$ & $18 / 6$ \\
\hline Identity style & Informative & $40 / 57$ & $4 / 82$ \\
\cline { 2 - 4 } & Normative & $32 / 28$ & $3 / 92$ \\
\cline { 2 - 4 } & Confused & $29 / 45$ & $5 / 51$ \\
\cline { 2 - 4 } & Commitment & $36 / 76$ & $5 / 81$ \\
\hline Religious orientation & - & $54 / 07$ & $6 / 47$ \\
\hline Emotional maturity & Emotional instability & $24 / 42$ & $5 / 96$ \\
\cline { 2 - 4 } & Emotional regression & $21 / 52$ & $5 / 82$ \\
\cline { 2 - 4 } & Personality collapse & $20 / 76$ & $5 / 36$ \\
\cline { 2 - 4 } & Social incompatibility & $18 / 10$ & $5 / 32$ \\
\cline { 2 - 4 } & Lack of independence & $18 / 36$ & $3 / 83$ \\
\hline
\end{tabular}

Table 2 shows the relationship between variables and subscales by Pearson correlation method. According to the results, there was no significant relationship between religious orientation and marital infidelity. On the other hand, there was a significant relationship between emotional maturity and confused style and commitment with marital infidelity. 
Table 2. Correlation between variables

\begin{tabular}{|c|c|c|c|c|c|c|}
\hline Variable & 1 & 2 & 3 & 4 & 5 & 6 \\
\hline 1. Marital infidelity & - & & & & & \\
\hline $\begin{array}{l}\text { 2. Informative } \\
\text { Identity style }\end{array}$ & $-0 / 152$ & - & & & & \\
\hline $\begin{array}{l}\text { 3. Normative } \\
\text { Identity style }\end{array}$ & $-0 / 175$ & $0 / 421 * *$ & - & & & \\
\hline $\begin{array}{l}\text { 4. Confused Identity } \\
\text { style }\end{array}$ & $0 / 227 *$ & $0 / 077$ & $0 / 068$ & - & & \\
\hline 5. Commitment & $-0 / 394 * *$ & $0 / 40 * *$ & $0 / 312 * *$ & $-0 / 282 * *$ & - & \\
\hline $\begin{array}{c}\text { 6. Religious } \\
\text { orientation } \\
\end{array}$ & $0 / 006$ & $0 / 20 *$ & $0 / 227 *$ & $0 / 163$ & $-0 / 013$ & - \\
\hline $\begin{array}{l}\text { 7. Emotional } \\
\text { maturity }\end{array}$ & $-0 / 377 * *$ & $-0 / 228^{*}$ & $-0 / 103$ & $0 / 251 * *$ & $0 / 355^{* *}$ & $0 / 037$ \\
\hline
\end{tabular}

Stepwise regression was used to examine the main hypothesis of the research and the prediction of marital infidelity based on predictive variables (identity styles "informative, normative, confused styles and commitment", religious orientation and emotional maturity). The results of Table 3 indicated that committed identity and emotional maturity in two steps were able to predict $22 \%$ of variance of marital betrayal significantly.

Table 3. Regression model

\begin{tabular}{cccccccc}
\hline Model & $\mathrm{R}$ & $\mathrm{R}^{2}$ & $\mathrm{R}^{2}$ Change & $\mathrm{Df}_{1}$ & $\mathrm{Df}_{2}$ & Sig. & Durbin-Watson \\
\hline 1 & $0 / 394$ & $0 / 155$ & $0 / 155$ & 1 & 119 & $0 / 0001$ & $1 / 92$ \\
\hline 2 & $0 / 468$ & $0 / 219$ & $0 / 064$ & 1 & 118 & $0 / 002$ & \\
\hline
\end{tabular}

In Table 4, the results of variance analysis of the regression model are presented. The results indicated that the analysis is significant in two steps.

Table 4. Variance analysis of the regression model

\begin{tabular}{|c|c|c|c|c|c|c|}
\hline & Model & Sum of Square & Df & Mean of Square & $\mathrm{F}$ & Sig. \\
\hline \multirow[t]{3}{*}{1} & Regression & $6445 / 59$ & 1 & $6445 / 59$ & \multirow[t]{3}{*}{$21 / 85$} & \multirow[t]{3}{*}{$0 / 0001$} \\
\hline & Residual & $35101 / 38$ & 119 & $294 / 97$ & & \\
\hline & Total & $41546 / 97$ & 120 & & & \\
\hline \multirow[t]{3}{*}{2} & Regression & $9110 / 72$ & 2 & $4555 / 36$ & \multirow[t]{3}{*}{$16 / 57$} & \multirow[t]{3}{*}{ 0/0001 } \\
\hline & Residual & $32436 / 24$ & 118 & $274 / 88$ & & \\
\hline & Total & $41546 / 97$ & 120 & & & \\
\hline
\end{tabular}

In Table 5, the standard and non-standard coefficients of predictive variables are presented for predicting marital infidelity. According to the results, emotional maturity and identity styles had a significant and negative relationship with marital infidelity. So, based on the model and standard coefficients, regression equation was:

Marital infidelity $=-0 / 298$ commitment $-0 / 271$ emotional maturity 
Table 4. Non-standard and standard coefficients of regression models

\begin{tabular}{|c|c|c|c|c|c|c|c|c|}
\hline \multirow[t]{2}{*}{$\begin{array}{l}\text { Mode } \\
1\end{array}$} & \multirow[t]{2}{*}{ Variable } & \multicolumn{2}{|c|}{$\begin{array}{l}\text { Non-standard } \\
\text { Coefficients }\end{array}$} & \multirow{2}{*}{$\begin{array}{c}\text { Standard } \\
\text { Coefficient } \\
\text { s }\end{array}$} & \multirow[t]{2}{*}{$\mathrm{T}$} & \multirow[t]{2}{*}{ Sig. } & \multirow[t]{2}{*}{$\begin{array}{c}\text { Toleranc } \\
\mathrm{e}\end{array}$} & \multirow[t]{2}{*}{ VIF } \\
\hline & & B & $\begin{array}{c}\text { Std.erro } \\
\mathrm{r}\end{array}$ & & & & & \\
\hline \multirow[t]{2}{*}{1} & Constant & $\begin{array}{c}105 / 5 \\
7 \\
\end{array}$ & $10 / 03$ & - & $\begin{array}{c}10 / 5 \\
1\end{array}$ & $\begin{array}{c}0 / 000 \\
1 \\
\end{array}$ & - & - \\
\hline & $\begin{array}{c}\text { Commitme } \\
\text { nt }\end{array}$ & $-1 / 26$ & $0 / 27$ & $-0 / 394$ & $\begin{array}{c}- \\
4 / 67\end{array}$ & $\begin{array}{c}0 / 000 \\
1\end{array}$ & 1 & 1 \\
\hline \multirow[t]{3}{*}{2} & Constant & $67 / 86$ & $15 / 51$ & - & $4 / 37$ & $\begin{array}{c}0 / 000 \\
1 \\
\end{array}$ & - & - \\
\hline & $\begin{array}{c}\text { Commitme } \\
\mathrm{nt}\end{array}$ & $\begin{array}{c}- \\
0 / 953\end{array}$ & $0 / 278$ & $-0 / 298$ & $\begin{array}{c}- \\
3 / 42\end{array}$ & $0 / 001$ & $0 / 87$ & $\begin{array}{c}1 / 1 \\
4\end{array}$ \\
\hline & $\begin{array}{c}\text { Emotional } \\
\text { maturity }\end{array}$ & $\begin{array}{c}- \\
0 / 256 \\
\end{array}$ & $0 / 082$ & $-0 / 271$ & $\begin{array}{c}- \\
3 / 11 \\
\end{array}$ & $0 / 002$ & $0 / 87$ & $\begin{array}{c}1 / 1 \\
4\end{array}$ \\
\hline
\end{tabular}

\section{Discussion}

The results showed that there was no significant relationship between religious orientation and marital infidelity. Hence, the first sub-hypothesis of the research was rejected. This finding was not in line with the findings of Gordon and Baucom (2004). However, there was a significant relationship between emotional maturity and marital infidelity. Therefore, the second hypothesis of the research was not rejected. The results also showed that from the four identity styles, only confused and committed identity styles are related to marital infidelity. Regression results showed that commitment and emotional maturity style in two steps predict approximately $22 \%$ of variance of marital betrayal. Therefore, the main hypothesis of the research was not rejected. In personality studies, identity is an intrinsic aspect which is associated with his past and has a sense of continuity and integrity in life. In other words, the identity is the individual's conception of the person and is used with various titles of gender identity, group identity, racial identity, etc. (Turner, 1985). Berzonsky proposed the model of identity and addressed the differences of individuals in the use of cognitive social process, such as decision-making, problem solving, dealing with problems, engaging with homework, and having a general cognitive health. Based on this pattern, Berzonsky in 1989 identified normative, confusing/avoidance, and informational styles (Berzonsky, 2002). Successful identity has a high psychological value as an indicator of flourishing personality. The most basic task of each person in life, from infancy to adolescence and adulthood, is to become aware and to accept "self," meaning that the person should try to feel the sense of his/her identity (Berzonsky, 2002). Naturally, the commitment of married couple in the family helps in ensuring the preservation of the family framework as a preventative factor in betraying. Therefore, the results of this 
study are consistent with the framework of identity theories. Identity organizes one's inner self, including self-construction, which is a system of beliefs, aspirations, beliefs, skills, and history that is actually the result of a crisis. Also, identity as an internal structure with a dynamic organization of personalities, abilities, beliefs, and individual histories appears as a preventative factor in betrayal in statistical models. Another variable that predict marital infidelity in our study was emotional maturity. Emotional maturity has a huge impact on personal life and strength, sustainability, and the improvement of social life. That is, it can be very effective in improving social relationships and family relationships and would help in terms of continuity and effectiveness. Emotional maturity is the skill and ability to control and manage emotions and feelings that make the right impression and appropriate use of emotions in different situations of life. Maturity is a general and a multidimensional phenomenon and the most prominent symptom of emotional maturity is the ability to withstand stress (Johnson, 2005). When we assume that the individual is emotionally mature, one knows correctly all his feelings and emotions and how to express and control it correctly. This factor is very effective in preventing marital betrayal, because the results of couple's clinical interviews showed that couples tend to be betrayed in a tense situation. Therefore, the finding has been quite logical. Individuals who are emotionally matured have the following characteristics: wanting to be with the opposite sex, understanding the attitudes and behavior of others, the desire to accept the attitudes and habits of others, and the ability to delay their responses. A person with emotional maturity finds more complex solutions for his everyday emotional problems, uses his feelings more complexly to solve these problems, and has the ability to control intense fluctuations of his feelings (Dutta \& Rajkonwar, 2016). These indicators explain the findings of this study. Therefore, puberty result to the advantage of various strategies and it minimizes marital deviance under stressful conditions. According to the results of this study, religion cannot predict marital betrayal. In addition, the explanation that can be presented in this regard is that the talent of betrayal is likely to be more radical than being obstructed by social norms and religion. Perhaps, if the betrayal rather than betrayal intention was evaluated, the religiosity could predict infidelity. However, religion as a deterrent variable in Iran can possibly influence the family, but the nature and essence of sexual diversity will not be eroded by the religiosity of individuals. Also, this talent as an evolutionary and unconsciousness factor still persists in people's tendencies. Moreover, if we examine the behavior of betrayal and its prevalence, religiosity could be deterrent. Hence, this idea can be considered in future investigations to show and clear up its role. One of the limitations of the present research was that the sample was limited to Tehran by available sample. 


\section{Conclusion}

Considering the prevalence of betrayal in Iranian society and the importance of examining its predicting variables, the purpose of this study was to determine the predictors of marital infidelity regarding the identity style, religious orientation, and emotional maturity in married individuals. The results showed that commitment and emotional maturity of couples, significantly predicts the talent of betrayal. Therefore, we suggest to family counselors and psychologists to consider the degree of emotional maturity and the identity style of couples as predictive factors of talent of infidelity in premarital counseling. Also, future researchers should repeat the research using other samples and the use of predictive variables in their interventions and evaluation of its effectiveness. Also, we suggest that researchers should study the extent of matching emotional maturity and identity styles of couples in predicting marital infidelity.

\section{References:}

1. Allport, G. (1968). The person in psychology, Boston, Beacon Press.

2. Allport, G.W. (1950). Pattern and growth in personality, New York: Holt.

3. Amato, P. R. \& Rogers, S. J. (1997). A longitudinal study of marital problems and subsequent divorce, Journal of Marriage and Family 1997, 59(3), 612-24.

4. Aviram, I. \& Amichai-Hamburger, Y. (2005). Online infidelity: Aspects ofdyadic satisfaction, self-disclosure, and narcissisms. Journal of Comput Mediat Commun; 10: 74-84.

5. Berzonsky, M. D. (1989). Identity style: Conceptualization and measurement, Journal of Adolescent Research, 4,pp 267-81.

6. Berzonsky, M.D. (2002). Self-construction over the life-span: A process perspective on identity formation, In: G.J. Neimeyer and R.A. Neimeyer, Editors, Advances in personal construct psychology, 1, JAI, Greenwich, CT, pp 155-186.

7. Brown, E. M. (2001). Patterns of infidelity and their treatment, New York, Brunner/Mazel.

8. Dutta, J. \& Rajkonwar, S. (2016). A Study on Emotional Maturity and Intelligence of Secondary School Students of Assam, International Journal of Science and Research, 5(12): 855-62.

9. Glass, S. P. \& Wright, T. L. (2007). Reconstructing marriages after the trauma of infidelity, In: Halford WK, Markman HJ, editors, Clinical handbook of marriage and couples interventions. New York, NY: John Wiley \& Sons, pp 471-507. 
10. Gordon, K.C. \& Baucom, D. H. (2004). Understanding betrayals in marriage: A synthesized model of forgiveness, Journal of Fam Process, 37(4), pp 425-449.

11. Johnson, S. M., (2005). Broken Bonds: An Emotionally Focused Approach to Infidelity, $J$ Couple \& Relat Ther, 4, pp 17-29.

12. Marami, A. \& Khademi, O. (2013). Marital betrayal talents, Psychology Department, Faculty of Humanities, Science and research Branch.

13. Peleg, O. (2008). The Relation Between Differentiation of Self and Marital Satisfaction: What Can Be Learned From Married People Over the Course of Life? The American Journal of Family Therapy, 36, pp 388-401.

14. Rubinstein Nabarro, N. \& Ivanir, S. (1999). "La terapia delle coppie di mezza età in crisi per una relazione extraconiugale" in Andolfi, M. (a cura di) La crisi della coppia. Una prospettiva sistemico-relazionale, Raffaello Cortina, Milano.

15. Singh, Y. \& Bhargave, M. (1981). Life Skill Education for High School students -A feasibility study in Mangalore Taluk.

16. Snyder, D. K., Baucom, D. H., \& Gordon, K. C. (2008). An Integrative Approach to Treating Infidelity, Counseling and Therapy for Couples and Families, 16(4); 300-307.

17. Teimoori, AA., Qolamali Lawasani, M., \& Bakhshayesh, AR. (2013). Predicting Marital Satisfaction on the Basis of Attachment Styles and Differentiation of Self. Journal of Family Research, 8(4); 441-463.

18. Tsapelas, I., Fisher, HE., \& Aron, A. (2010). "Infidelity: when, where, why." IN WR Cupach and BH Spitzberg, the Dark Side of Close Relationships II, NewYork: Routledge, pp 175-196.

19. Turner, J. C. (1985). Social categorization and the self-concept: A social cognitive theory of group behavior, In E.J., Lawler (Ed.), Advances in group processes: Theory and research, vol. 2, pp 77-121, Greenwich, CT: JAI Press, 1985.

20. Whitty, M.T. (2002). Liar, liar! An examination of how open, supportive and honest people are in chat rooms, Computers in Human Behavior, 18(4), pp 343-352. 